\title{
A Engenharia Química e o Meio Ambiente
}

A Vigésima Sétima Edição do Congresso Nacional dos Estudantes de Engenharia Química, CONEEQ, irá acontecer na Universidade Federal de Goiás, campus Goiânia, nos dias 14 a 21 de janeiro de 2018. O CONEEQ é um evento de caráter técnico-científico e social, itinerante e sem fins lucrativos, realizado por estudantes da Engenharia Química brasileira. A programação é constituída de palestras, minicursos, mostra de iniciação científica, visitas técnicas, Encontro de Entidades Estudantis da Engenharia Química, mesa redonda, eventos culturais.

O objetivo geralé promover o intercâmbio de conhecimento entre acadêmicos das diversas instituições de ensino superior em Engenharia Química e áreas afins. Este é um dos pontos bastante positivo do evento, uma vez que a integração de alunos de diferentes regiões e contextos é enriquecedora.

Goiânia, a capital do estado de Goiás sediará o evento. Localizada no coração do Brasil a cidade conta com a Universidade Federal de Goiás, fundada em 1960, através da união de cinco escolas superiores que existiam em Goiânia.

Em 2009 foi criado o curso de Engenharia Química no Instituto de Química. O curso pretende formar profissionais generalistas capacitados a atuar em todos os setores da indústria, assim como acompanhar os processos industriais em todos os seus níveis.

O tema que conduzirá as atividades do congresso será "Engenharia Química, Indústria e Meio Ambiente, como concilia-los?". Este tema é de extrema relevância ao precisar exercer a capacidade do ser humano de interagir com o mundo preservando o meio ambiente para que não haja, ainda mais, o comprometimento dos recursos naturais para as futuras gerações.

Ao tratar de sustentabilidade é necessário considerar a questão energética de grande importância para o desenvolvimento econômico.

A economia de Goiás está baseada na produção agrícola, na pecuária, no comércio, nas indústrias de mineração, alimentícia, de confecções, mobiliária e madeireira. O Distrito Agroindustrial de Anápolis (DAIA), localizado a 59,3 km de Goiânia, possui o maior pólo farmoquímico da América Latina.

Ao falar de meio ambiente não significa necessariamente deixar passar as oportunidades de realizar bons negócios e de reduzir custos de produção. É, pois, justamente fazendo estas observações que podemos identificar e sanar a má utilização de recursos. A reciclagem é um ótimo exemplo da utilização de resíduos que seriam descartados, em novos materiais, gerando a economia de recursos.

Conservar energia, água e outros recursos naturais é reduzir custos de produção. O Engenheiro Químico é um profissional capacitado a buscar soluções que conciliem indústria e meio ambiente.

O público alvo para este evento são alunos de Engenharia Química e os profissionais de áreas afins que tenham interesse pelas atividades acadêmicas ofertadas. A estrutura da UFG estará à disposição para que os congressistas tenham uma semana proveitosa.

\section{Margarete Martins Pereira Ferreira}

Instituto de Química, Universidade Federal de Goiás, 74001-970, Goiânia, Goiás, Brasil.

E-mail: margarete_martins@yahoo.com.br 